\title{
VALIDASI REFLEKTAN PERMUKAAN HASIL DARI KOREKSI ATMOSFER METODE SEN2COR MENGGUNAKAN DATA IN SITU (STUDI KASUS: DANAU KASUMIGAURA, JEPANG)
}

\author{
Lalu Muhamad Jaelani ${ }^{1}$, Romadina Indah Wardani ${ }^{2}$ \\ 1,2Departemen Teknik Geomatika FTSLK-ITS, Kampus ITS Sukolilo, Surabaya, 60111 \\ e-mail : ${ }^{1}$ Imjaelani@geodesy.its.ac.id
}

\begin{abstract}
Abstrak
Salah satu manfaat penginderaan jauh adalah pemantauan Suspended Solid (SS) sebagai parameter kualitas air. Nilai estimasi SS umumnya tergantung pada keakuratan koreksi atmosfer dan model yang menghubungkan antara reflektan dengan parameter kualitas air yang akan diekstrak. Organisasi ESA (European Space Agency) mengeluarkan metode koreksi atmosfer Sen2Cor untuk citra satelit Sentinel-2. Dalam penelitian ini dilakukan validasi reflektan permukaan hasil koreksi atmosfer Sen2Cor dan hasil estimasi SS menggunakan data in situ yang diambil di Danau Kasumigaura, Jepang yang digunakan diambil pada tanggal 27 Oktober 2016 dan 29 November 2016. Validasi menggunakan metode uji koefisien determinasi $\left(R^{2}\right)$, RMSE dan NMAE. Hasil dari validasi reflektan permukaan terhadap data in situ untuk uji $\mathrm{R}^{2}$, RMSE dan NMAE masing-masing sebesar 0,737; 0,004; dan 114,087\%. Berdasarkan nilai tersebut, reflektan permukaan dianggap tidak akurat untuk digunakan dalam perhitungan ekstraksi parameter kualitas air, dikarenakan syarat nilai NMAE untuk melakukan ektraksi parameter kualitas air adalah $\leq 30 \%$. Sedangkan, validasi estimasi SS terhadap data in situ untuk uji $\mathrm{R}^{2}$, RMSE dan NMAE masing-masing menghasilkan nilai sebesar 0,153; 5,665; dan 24,965\%. Meskipun nilai NMAE memenuhi syarat, namun untuk nilai $\mathrm{R}^{2}$ dan RMSE menghasilkan nilai yang tidak akurat. Maka, hal ini membuktikan bahwa akurasi nilai reflektan permukaan sangat mempengaruhi hasil estimasi SS.
\end{abstract}

Kata Kunci : Reflektan, Suspended Solid, Koreksi Atmosfer, Sen2Cor, Danau Kasumigaura.

\begin{abstract}
One of benefits of remote sensing is Suspended Solid (SS) monitoring as a water quality parameter. SS estimation values are generally depend on the accuracy of the atmospheric correction and the model that relate between the reflectance with the water quality parameters to be extracted. The ESA (European Space Agency) organization issued the Sen2Cor atmospheric correction method for Sentinel-2. This research will validate surface reflectance from Sen2Cor atmospheric correction results and SS estimation results using in situ data taken at Lake Kasumigaura, Japan on October 27, 2016 and November 29, 2016. Validation using $R^{2}, R M S E$ and NMAE. The results of surface reflectance validation of in situ data for $R^{2}, R M S E$ and NMAE tests were 0.737; 0.004; and 114.087\%. Based on these values, surface reflectance is considered inaccurate for water quality parameter extraction, because the NMAE value requirement for extraction of water quality parameters is $\leq 30 \%$. Meanwhile, The validation result of SS estimation using in situ data for the test of $R^{2}$, RMSE, and NMAE is 0,153; 5,665; and 24.965\%. Although the NMAE value is eligible, however for $R^{2}$ and RMSE values is inaccurate. Thus, this proves that the accuracy of the surface reflectance value greatly influences the SS estimation results.
\end{abstract}

Keywords: Reflectance, Suspended Solid, Atmospheric Correction, Sen2Cor, Lake Kasumigaura 


\section{PENDAHULUAN}

Penginderaan jauh merupakan salah satu teknologi yang sering digunakan pada era modern ini. Penginderaan jauh memanfaatkan radiasi gelombang elektromagnetik untuk memperoleh informasi tentang laut, tanah dan atmosfer tanpa melakukan kontak fisik secara langsung dengan objek, permukaan atau fenomena yang sedang diamati (Martin, 2004). Pemanfaatan penginderaan jauh, nampaknya sudah berkembang dalam berbagai bidang. Seperti dalam bidang kehutanan, pertanian, pertambangan, pemantauan daerah terdampak banjir, pengamatan deformasi, dan lain sebagainya.

Salah satu manfaat lain penginderaan jauh yang tak kalah penting adalah pemantauan Suspended Solid (SS) sebagai salah satu parameter kualitas air. Nilai estimasi SS diperoleh dari reflektan yang terdapat pada citra satelit. Pada umumnya, produk reflektan yang diperoleh saat mengunduh citra satelit, masih berupa reflektan sensor atau Top-of-Atmospher reflectance (TOA reflectance). Untuk bisa diolah menjadi estimasi SS pada suatu area, reflektan sensor perlu diubah menjadi reflektan permukaan atau Bottom-ofAtmospher (BOA reflectance) biasa disebut surface reflectance. Hal ini dilakukan dengan cara melakukan koreksi atmosfer terhadap reflektan sensor.

Tujuan dari koreksi atmosfer adalah untuk menghilangkan efek atmosfer dari data yang direkam, sehingga akan menghasilkan peningkatan akurasi dari reflektan (Ruddick, Ovidio, \& Rijkeboer, 2000). Terdapat berbagai metode koreksi atmosfer yang dapat digunakan, salah satunya adalah metode Sen2Cor. Koreksi atmosfer Sen2Cor ini diluncurkan ESA (European Space Agency) sebagai metode khusus untuk citra satelit Sentinel-2. Dengan metode Sen2Cor, koreksi atmosfer dapat dilakukan dengan mudah dan cepat. Namun masalah yang harus dihadapi para peniliti saat melakukan koreksi atmosfer dengan metode ini adalah nilai akurasi dari data yang diperoleh.

Untuk menjawab masalah tersebut, pada penelitian ini akan dilakukan uji akurasi produk reflektan permukaan hasil dari koreksi atmosfer pada citra dengan metode Sen2Cor terhadap data insitu reflektan permukaan. Data in situ diambil dari 5 stasiun pengamatan di Danau Kasumigaura. Selain uji akurasi terhadap reflektan permukaan, dalam penelitian ini juga dilakukan uji akurasi terhadap nilai SS yang dihasilkan dari citra satelit Sentinel-2, terhadap data SS in situ sehingga akan diketahui bagaimana pengaruh dari koreksi atmosfer Sen2Cor terhadap nilai SS yang dihasilkan.. Dengan penelitian ini diharapkan dapat digunakan sebagai bahan pertimbangan dalam pengambilan keputusan atau sebagai acuan dalam penelitian selanjutnya yang berhubungan dengan koreksi atmosfer metode Sen2Cor.

\section{METODOLOGI PENELITIAN}

\section{Lokasi Penelitian}

Lokasi yang digunakan pada penelitian ini adalah Danau Kasumigaura, Jepang, dengan koordinat $35^{\circ} 57^{\prime} 3,30^{\prime \prime}$ - 36 9'40,67" LU dan 140¹1'52,06" $140^{\circ} 12^{\prime} 10,00^{\prime \prime}$ BT. Danau Kasumigaura terletak sekitar 60-90 km timur laut dari Tokyo, di bagian tenggara dari Prefektur Ibaraki, dan danau ini merupakan danau terbesar kedua di Jepang setelah Danau Biwa. Luas Danau Kasumigaura adalah $220 \mathrm{~km}^{2}$, dengan rata-rata kedalaman adalah $4 \mathrm{~m}$, dan maksimum kedalaman adalah 7 meter. Berikut merupakan gambar lokasi penelitian.

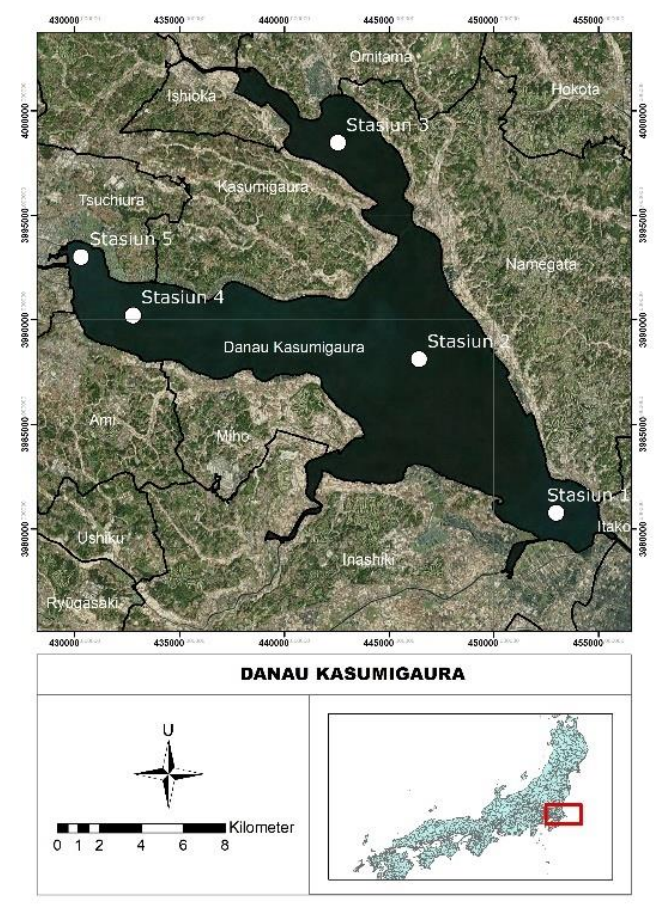

Gambar 1. Lokasi Penelitian

\section{Data dan Peralatan}

Data yang digunakan dalam penelitian ini adalah citra satelit serta data in situ. Data in situ yang 
digunakan terdiri dari 2 jenis yaitu data in situ Remote Sesing Reflectance $(\operatorname{Rrs}(\lambda))$ dan data in situ Suspended Solid (SS) dengan satuan mg/L. Kedua data ini diambil pada tanggal 27 Oktober 2016 dan 29 November 2016. Sedangkan untuk citra satelit yang digunakan adalah Sentinel-2 L1C dengan tanggal akuisisi yang disesuaikan dengan data in situ, yaitu tanggal 27 Oktober 2016 dan 29 November 2016.

Tabel 1. Koordinat Stasiun pengambilan Data in situ

\begin{tabular}{cccc}
\hline Tanggal & Stasiun & Bujur & Lintang \\
\hline & 1A & $140^{\circ} 28^{\prime} 42.7^{\prime \prime}$ & $35^{\circ} 58^{\prime} 12.4^{\prime \prime}$ \\
27 & 2A & $140^{\circ} 24^{\prime} 19.2^{\prime \prime}$ & $36^{\circ} 02^{\prime} 09.7^{\prime \prime}$ \\
Oktober & 3A & $140^{\circ} 21^{\prime} 41.7^{\prime \prime}$ & $36^{\circ} 07^{\prime} 45.0^{\prime \prime}$ \\
2016 & $4 \mathrm{~A}$ & $140^{\circ} 15^{\prime} 13.2^{\prime \prime}$ & $36^{\circ} 03^{\prime} 14.9^{\prime \prime}$ \\
& A & $140^{\circ} 13^{\prime} 33.1^{\prime \prime}$ & $36^{\circ} 04^{\prime} 44.8^{\prime \prime}$ \\
& $1 \mathrm{~B}$ & $140^{\circ} 28^{\prime} 45.5^{\prime \prime}$ & $35^{\circ} 58^{\prime} 16.7^{\prime \prime}$ \\
29 & 2B & $140^{\circ} 24^{\prime} 24.8^{\prime \prime}$ & $36^{\circ} 02^{\prime} 07.8^{\prime \prime}$ \\
November & 3B & $140^{\circ} 21^{\prime} 13.6^{\prime \prime}$ & $36^{\circ} 07^{\prime} 53.8^{\prime \prime}$ \\
2016 & B & $140^{\circ} 15^{\prime} 16.0^{\prime \prime}$ & $36^{\circ} 03^{\prime} 14.1^{\prime \prime}$ \\
& 5B & $140^{\circ} 13^{\prime} 52.8^{\prime \prime}$ & $36^{\circ} 04^{\prime} 33.3^{\prime \prime}$ \\
\hline
\end{tabular}

Tabel 2. Scene Citra Satelit Sentinel-2 L1C yang digunakan

\begin{tabular}{cl}
\hline Tanggal & \multicolumn{1}{c}{ ID Scene } \\
\hline & S2A_OPER_MSI_L1C_TL_SGS_2016102 \\
27 & 7T012817_20161027T044719_A00703 \\
Oktober & 5_T54SVE_N02_04_01 \\
2016 & S2A_OPER_MSI_L1C_TL_SGS_2016102 \\
& 7T012817_20161027T044719_A00703 \\
& 5_T54SVF_N02_04_01 \\
& S2A_OPER_MSI_L1C_TL_SGS_201611 \\
29 & 29T013814_20161129T064027_A0075 \\
November & 07_T54SVF_N02_04_01 \\
2016 & S2A_OPER_MSI_L1C_TL_SGS_201611 \\
& 29T013814_20161129T064027_A0075 \\
& 07_T54SVE_N02_04_01 \\
\hline
\end{tabular}

Adapun peralatan yang digunakan dalam penelitian ini terdiri dari perangkat keras (Hardware) berupa laptop, fieldspectoradiometer dan GPS Handheld serta perangkat lunak (software) pengolah penginderaan jauh, seperti SNAP, ArcGIS dan perangkat lunak pengolah penginderaan jauh lainnya.

\section{Tahap Pengolahan Data}

Adapun tahapan pengolahan data yang dilakukan adalah sebagai berikut:

a. Klasifikasi $\operatorname{Rrs}(\lambda)$ in situ berdasarkan panjang gelombang pada band Sentinel-2. b. Melakukan koreksi atmosfer pada citra satelit Sentinel-2 Level-1C menggunakan metode Sen2Cor yang dilakukan pada SNAP. Proses ini dilakukan untuk mengubah produk reflektan, dari reflektan sensor (Top-Of-Atmosphere (TOA)), yang kemudian menghasilkan Sentinel-2 Level-2A yang dalam bentuk reflektan permukaan (surface reflectance, Bottom-OfAtmosphere (BOA)).

c. Data surface reflektance harus di ubah menjadi Remote Sensing Reflektance $\operatorname{Rrs}(\lambda)$ (dalam satuan $\mathrm{sr}^{-1}$ ) agar memiliki satuan yang sama dengan reflektan in situ, sehingga bisa dibandingkan. Hal ini dilakukan dengan cara masing-masing band sr dibagi dengan $\pi$.

d. Perhitungan SS ini bertujuan untuk menghasilkan nilai SS sesuai koordinat stasiun pengambilan data in situ SS. Perhitungan SS menggunakan algoritma Jaelani (2016), yang dilakukan pengembangan, karena menyesuaikan lokasi studi kasus pada penelitian ini. Dengan menggunakan algoritma regresi linier sederhana. Analisis regresi (regression analysis) merupakan suatu teknik untuk membangun persamaan dan menggunakan persamaan tersebut untuk membuat perkiraan (prediction). Dengan persamaan umumnya adalah sebagai berikut:

$$
\mathrm{Y}=\mathrm{aX}+\mathrm{b}
$$

Dimana pada penelitian ini yang berperan sebagai variabel terikat $(\mathrm{Y})$ adalah data SS in situ, sedangkan variabel bebas $(X)$ adalah data $\operatorname{Rrs}(\lambda)$ in situ. Koefisien a adalah konstanta (intercept) yang merupakan tiitk potong antara garis regresi dengan sumbu $Y$ pada koordinat kartesius.

e. Ekstraksi nilai $\operatorname{Rrs}(\lambda)$ dan SS pada setiap stasiun. Proses ini dilakukan dengan tujuan untuk mengetahui nilai $\operatorname{Rrs}(\lambda)$ pada setiap stasiun. Proses ekstraksi dilakukan dengan ukuran jendela $3 \times 3$ piksel. Hal ini penting dilakukan karena : (1) untuk menghindari kemungkinan adanya kesalahan dalam koreksi geometrik dan dinamika badan air, penggunaan jendela piksel untuk menghindari kesalahan karena perbedaan koordinat yang mungkin terjadi jika hanya menggunakan satu piksel; dan (2) jendela piksel memberi perkiraan variabilitas spasial (Han \& Jordan, 2005) . 
f. Uji akurasi menggunakan Determination Coefficient $\left(\mathrm{R}^{2}\right)$, Root Mean Square Error (RMSE) dan Normalized Mean Absolute Error (NMAE), dengan rumus seperti berikut :

$$
\begin{aligned}
& \text { RMSE }=\sqrt{\frac{\sum_{i=1}^{N}\left(x_{\text {esti, } i}-x_{\text {meas }, i}\right)^{2}}{N}} \\
& \operatorname{NMAE}(\%)=\frac{1}{N} \sum_{i=1}^{N}\left|\frac{x_{\text {esti, } i}-x_{\text {meas }, i}}{x_{\text {meas }}}\right| \times 100
\end{aligned}
$$

Dimana $x_{\text {meas }}$ merupakan nilai dari data in situ, sedangkan $x_{\text {esti }}$ merupakan nilai dari data yang diperoleh dari estimasi oleh citra satelit Sentinel-2. Uji akurasi menggunakan Determination Coefficient $\left(\mathrm{R}^{2}\right)$ untuk mengetahui tingkat kedekatan antara data in situ dengan data Sentinel 2 baik nilai $\operatorname{Rrs}(\lambda)$ maupun nilai SS.Selanjutnya adalah ujiakurasi menggunakan Root Mean Square Error (RMSE) dan Normalized Mean Absolute Error (NMAE). Semakin besar nilai RMSE maka data yng dimiliki semakin tidak akurat, dan berlaku sebaliknya. Sedangkan untuk nilai NMAE, minimum nilai NMAE agar bisa digunakan untuk mengekstrak data kualitas air dari data penginderaan jauh harus memiliki nilai dibawah 30\% (Jaelani dkk. 2015).

\section{HASIL DAN PEMBAHASAN}

\section{Validasi Remote Sensing Reflectance $(\operatorname{Rrs}(\lambda))$ dari Sentinel-2 dengan Data In Situ}

Nilai $\operatorname{Rrs}(\lambda)$ yang diperoleh dari citra satelit Sentinel-2 hasil koreksi atmosfer Sen2Cor divalidasi dengan $\operatorname{Rrs}(\lambda)$ in situ. Data in situ diambil pada 5 titik stasiun di Danau Kasumigaura menggunakan alat Field Spectroradiometer dengan panjang gelombang dari 350 sampai $1075 \mathrm{~nm}$ dan interval data $1 \mathrm{~nm}$. Dengan panjang gelombang tersebut, data in situ $\operatorname{Rrs}(\lambda)$ masuk sesuai dengan kanal Sentinel-2, yaitu kanal 1 sampai 9.

Namun, data dengan panjang gelombang lebih dari $800 \mathrm{~nm}$, tidak digunakan karena terjadi penyerapan maksimum oleh air, sehingga tidak ada informasi yang dapat diperoleh. Oleh karena itu, kanal yang digunakan adalah kanal 1 sampai 7 . Untuk data citra satelit pada tanggal akuisisi 27 Oktober 2016, dari 5 stasiun pengamatan, terdapat 2 stasiun yang tidak terekam pada citra satelit, yaitu stasiun 4 dan 5 . Sehingga untuk data citra satelit pada tanggal 27 Oktober 2016, yang bisa diperoleh hanya data pada stasiun 1, 2 dan 3 .
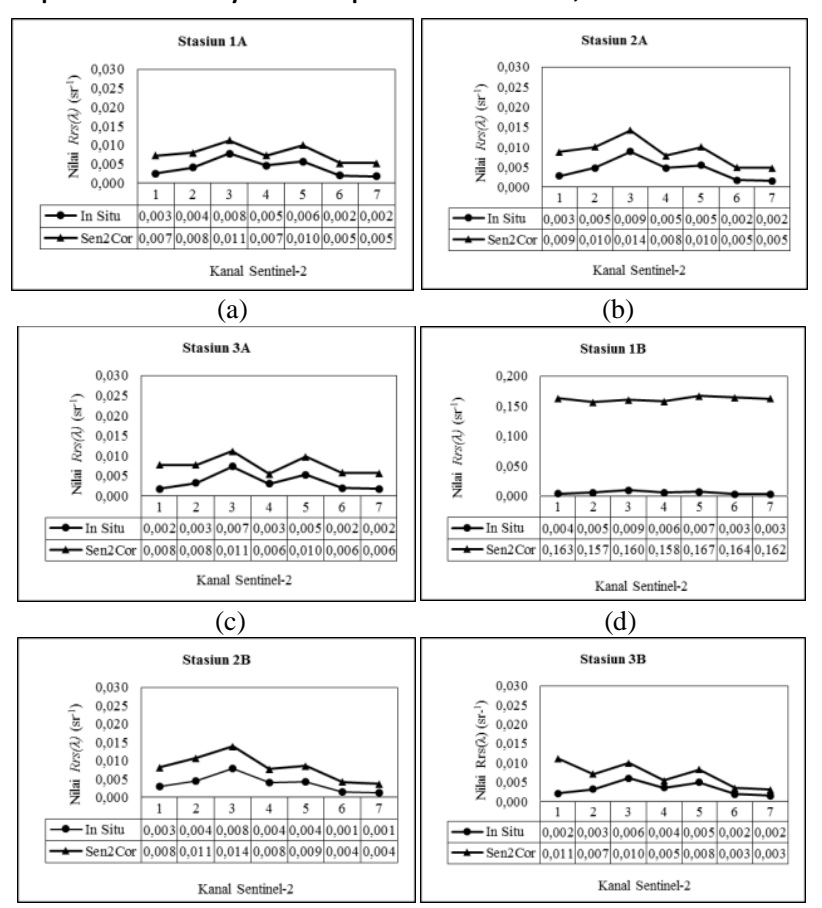

(e)

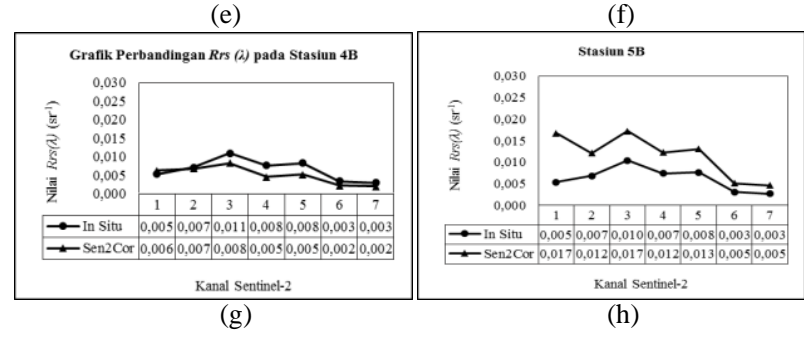

Gambar 2. Grafik Perbandingan Nilai $\operatorname{Rrs}(\lambda)$ Sen2Cor dengan $\operatorname{Rrs}(\lambda)$ in situ

Grafik pada Gambar 2 diatas menunjukkan nilai dari $\operatorname{Rrs}(\lambda)$ in situ dan nilai $\operatorname{Rrs}(\lambda)$ hasil dari citra satelit Sentinel-2 yang telah dikoreksi dengan koreksi atmosfer Sen2Cor. Stasiun $1 \mathrm{~A}$ sampai dengan stasiun $3 \mathrm{~B}$, merupakan data $\operatorname{Rrs}(\lambda)$ untuk tanggal 27 Oktober 2016, sedangkan stasiun 1B sampai stasiun 5B merupakan data $\operatorname{Rrs}(\lambda)$ untuk tanggal 29 November 2016. Berdasarkan grafik tersebut, nilai $\operatorname{Rrs}(\lambda)$ dari Sentinel-2, rata-rata memiliki nilai lebih besar dari nilai dari $\operatorname{Rrs}(\lambda)$ in situ, dengan dinamika perubahan yang serupa, kecuali pada stasiun $1 \mathrm{~B}$, dimana nilai $\operatorname{Rrs}(\lambda)$ dari Sentinel-2 memiliki perbedaan yang cukup jauh dari nilai $\operatorname{Rrs}(\lambda)$ in situ. Hal tersebut terjadi karena pada stasiun 1B di citra satelit Sentinel-2 tertutup oleh awan yang cukup tebal, sehingga informasi yang didapatkan bukanlah nilai $\operatorname{Rrs}(\lambda)$ pada permukaan danau, melainkan nilai pada 
permukaan awan yang ada diatasnya. Oleh karena itu, data pada stasiun $1 \mathrm{~B}$ ini, tidak digunakan pada perhitungan.

Berdasarkan Tabel 4 dapat diketahui bahwa nilai koefisien determinasi terbesar ditunjukkan oleh stasiun 2B yaitu sebesar 0,922 . Sedangkan untuk data $\operatorname{Rrs}(\lambda)$ dengan nilai $\mathrm{R}^{2}$ terendah ditunjukkan oleh stasiun $3 \mathrm{~B}$, yang bernilai sebesar 0,285. Dimana rata-rata nilai koefisien determinasi $\left(R^{2}\right)$ adalah sebesar 0,737 . Dengan nilai $\mathrm{R}^{2}$ tersubut, menunjukkan bahwa $\operatorname{Rrs}(\lambda)$-Sen2Cor mampu menggambarkan nilai $\operatorname{Rrs}(\lambda)$ in situ dengan baik, karena setiap perubahan nilai $\operatorname{Rrs}(\lambda)$-Sen2Cor, diikuti dengan perubahan $\operatorname{Rrs}(\lambda)$ in situ.

Tabel 4. Hasil Uji Koefisien Determinasi $\operatorname{Rrs}(\lambda)$ Hasil Koreksi Atmosfer Sen2Cor terhadap $\operatorname{Rrs}(\lambda)$ in situ

\begin{tabular}{ccc}
\hline Tanggal & Stasiun & $\mathrm{R}^{2}$ \\
\hline 27 & $1 \mathrm{~A}$ & 0,899 \\
Oktober & $2 \mathrm{~A}$ & 0,890 \\
2016 & $3 \mathrm{~A}$ & 0,787 \\
\hline \multirow{2}{*}{29} & $2 \mathrm{~B}$ & 0,922 \\
November & $3 \mathrm{~B}$ & 0,285 \\
2016 & $4 \mathrm{~B}$ & 0,702 \\
& $5 \mathrm{~B}$ & 0,671 \\
\hline \multicolumn{3}{c}{ Rata-rata } \\
\hline
\end{tabular}

Seperti halnya dengan uji koefisien determinasi, hasil uji RMSE pada $\operatorname{Rrs}(\lambda)$-Sen2Cor dengan $\operatorname{Rrs}(\lambda)$ in situ menunjukkan nilai yang baik dengan rata-rata 0,004 seperti ditunjukkan pada Tabel 5. Nilai RMSE yang kecil menunjukkan nilai error atau kesalahan perhitungan yang terjadi sedikit.

Tabel 5. Hasil Uji Akurasi Rrs( $\lambda$ ) Hasil Koreksi Atmosfer Sen2Cor terhadap $\operatorname{Rrs}(\lambda)$ In Situ

\begin{tabular}{cccc}
\hline Tanggal & Stasiun & RMSE $\left(\mathrm{sr}^{-1}\right)$ & NMAE (\%) \\
\hline \multirow{2}{*}{27 Oktober } & AA & 0,004 & 118,641 \\
2016 & 2A & 0,004 & 129,523 \\
& 3A & 0,004 & 157,667 \\
\hline \multirow{2}{*}{29} & 2B & 0,005 & 144,190 \\
November & 3B & 0,004 & 131,709 \\
2016 & 4B & 0,002 & 27,207 \\
& 5B & 0,006 & 89,668 \\
\hline \multicolumn{2}{c}{ Rata-rata } & 0,004 & 114,087 \\
\hline
\end{tabular}

Sedangkan untuk nilai NMAE, menghasilkan nilai terendah pada stasiun 4B, yakni sebesar 27,207\%, sedangkan nilai NMAE terbesar terdapat pada stasiun 3A, yakni sebesar $157,667 \%$. Rata-rata nilai NMAE menunjukkan angka sebesar adalah $114,087 \%$. Sementara syarat nilai NMAE untuk bisa melakukan ektraksi parameter kualitas air adalah $\leq 30 \%$. Sehingga secara kesuluruhan, berdasarkan uji akurasi yang dilakukan, nilai $\operatorname{Rrs}(\lambda)$ Sen2Cor pada penelitian ini dianggap tidak akurat untuk digunakan perhitungan ekstraksi parameter kualitas air.

\section{Validasi Suspended Solid dari Sentinel-2 dengan Data In Situ}

Perhitungan estimasi SS dilakukan menggunakan perangkat lunak SNAP 5.0 dengan menggunakan algoritma Jaelani (2016) ( (Jaelani dkk. 2016). Berdasarkan algoritma ini, akan dibuat algortima model baru untuk perhitungan sebaran estimasi SS di Danau Kasumigaura, Jepang. Pembuatan algoritma baru dibuat berdasarkan regresi linier sederhana $(Y=a x+b)$ dengan membandingkan data SS dengan data $\operatorname{Rrs}(\lambda)$ in situ. Pada Gambar 3 berikut merupakan model dari regresi linier yang dihasilkan.

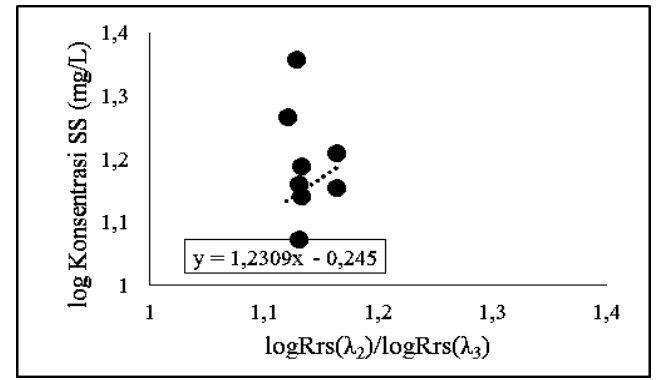

Gambar 3. Regresi Linier dari Rasio $\operatorname{Rrs}(\lambda)$ Kanal 2 dan 3 terhadap Konsentrasi SS (mg/L)

Berdasarkan persamaan regresi tersebut, diperoleh algoritma baru untuk menghitung dan mengetahui persebaran SS di Danau Kasumigaura, Jepang. Berikut merupakan algoritma model baru yang dihasilkan yaitu:

$\log (S S)=1,2309 \times\left(\frac{\log \operatorname{Rrs}\left(\lambda_{2}\right)}{\log \operatorname{Rrs}\left(\lambda_{3}\right)}\right)-0,245$

Dari algoritma model diatas, akan dihitung estimasi Suspended Solid (SS) pada danau Kasumigaura untuk tanggal 27 Oktober 2016 dan 29 November 2016. Hasil dari estimasi SS ini akan 
di validasi dengan data in situ SS, yang diambil sesuai dengan tanggal data citra satelit.

Tabel 4. Nilai Konsentrasi SS antara SS hasil perhitungan dengan SS In Situ.

\begin{tabular}{ccc}
\hline \multirow{2}{*}{ Tanggal } & \multicolumn{2}{c}{ Konsentrasi SS $(\mathrm{mg} / \mathrm{L})$} \\
\cline { 2 - 3 } & In Situ & Estimasi \\
\hline 27 & 13,844 & 12,053 \\
November & 14,467 & 12,149 \\
2016 & 16,267 & 12,245 \\
\hline & 15,444 & 10,353 \\
29 & 11,867 & 11,298 \\
November & 14,289 & 11,614 \\
2016 & 22,867 & 10,320 \\
& 18,500 & 12,082 \\
\hline
\end{tabular}

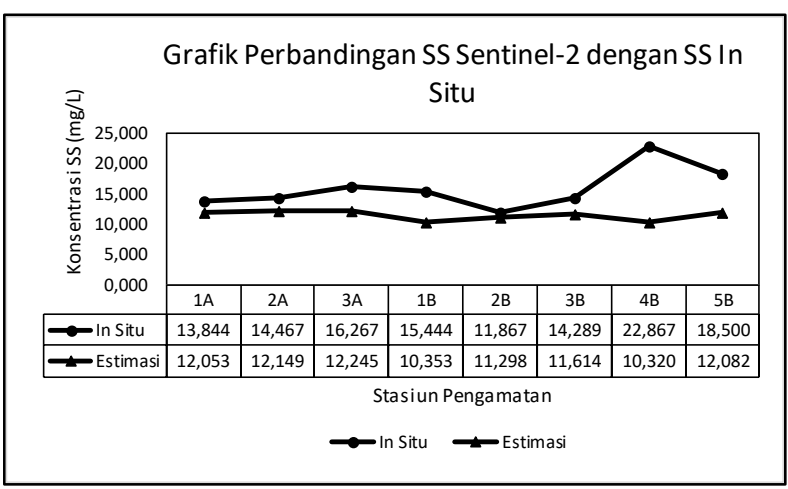

Gambar 4. Grafik Perbandingan Nilai $\operatorname{Rrs}(\lambda)$ in situ dengan $\operatorname{Rrs}(\lambda)$ koreksi Sen2Cor

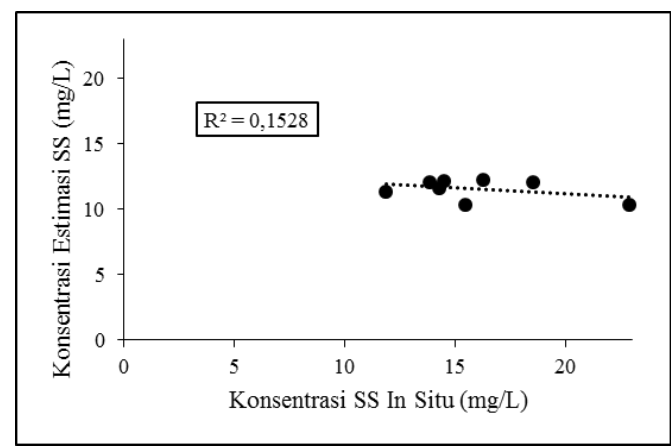

Gambar 5. Grafik Perbandingan Nilai $\operatorname{Rrs}(\lambda)$ in situ dengan $\operatorname{Rrs}(\lambda)$ koreksi Sen2Cor

Perbandingan nilai konsentrasi SS antara hasil estimasi dengan data in situ memiliki nilai RMSE yang sangat besar, yaitu sebesar 5,665 dan uji koefisien determinasi yang rendah pula, dengan nilai 0,153 . Hal ini membuktikan bahwa akurasi nilai $\operatorname{Rrs}(\lambda)$ sangat mempengaruhi hasil ekstraksi parameter kualitas perairan. Sehingga hal yang perlu diperhatikan dalam melakukan ekstraksi parameter kualitas perairan adalah syarat nilai NMAE kurang dari 30\% yang harus terpenuhi sehingga bisa memperoleh nilai ekstraksi yang mendekati dengan nilai yang dianggap benar.

\section{Estimasi Sebaran SS dengan Sentinel-2}

Berikut merupakan peta hasil estimasi persebaran SS pada Danau Kasumigaura untuk tanggal 27 Oktober 2016 (Gambar 6) dan 29 November 2016 (Gambar 7).

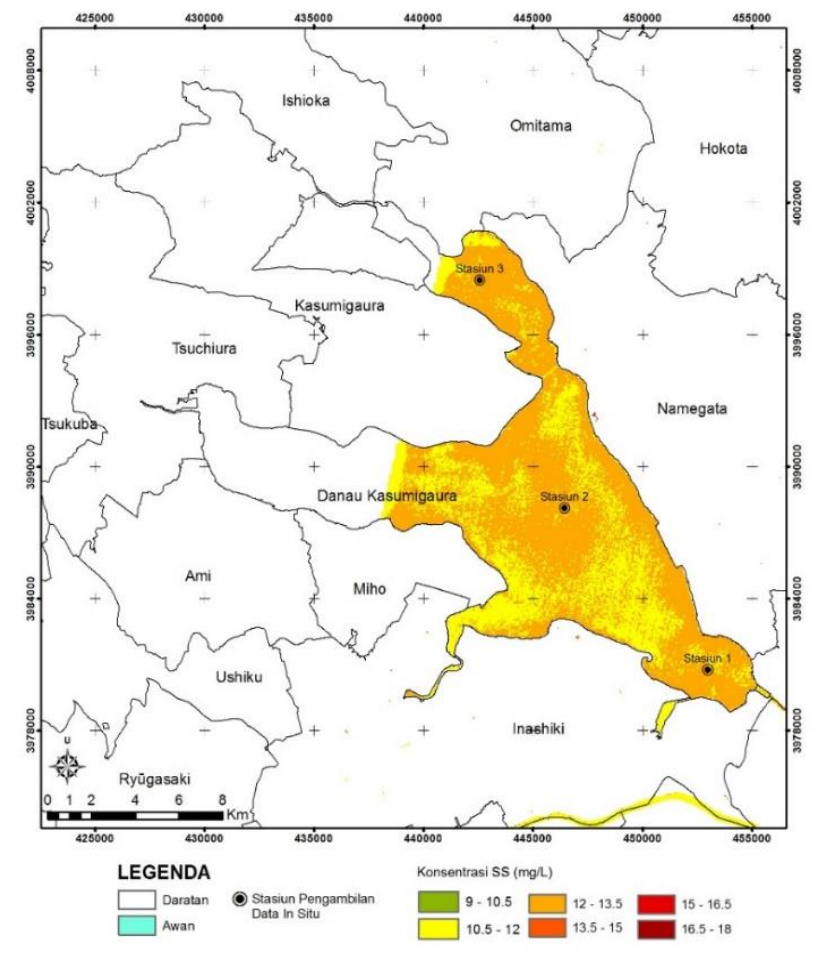

Gambar 6. Peta Estimasi Persebaran SS Danau Kasumigaura tanggal 27 Oktober 2016

Pada peta hasil estimasi ini, nilai SS dibagi menjadi 6 kelas, dari warna hijau sampai warna merah tua. Semakin merah, maka menunjukkan konsentrasi SS yang semakin besar. Dari peta yang dihasilkan, dapat dilihat bahwa konsentrasi SS pada tanggal 27 Oktober 2016, rata-rata memiliki nilai yang lebih besar dibandingkan dengan data SS pada tanggal 29 November 2016. Hal ini sesuai dengan data in situ SS yang digunakan sebagai acuan, pada data in situ tersebut, data SS pada tanggal 27 Oktober 2016 lebih besar nilainya daripada tanggal 29 November 2016. Dari data sebaran estimasi pada tanggal 27 Oktober, dapat diketahui bahwa nilai konsentrasi SS tinggi 
terdapat pada daerah tepi danau dan muara dari sungai Koiso. Hal ini terjadi karena besarnya distribusi partikel yang mengalir dari daratan menuju ke danau melalui sungai. Daerah tepi danau memiliki konsentrasi SS yang tinggi karena adanya proses erosi di tepi danau yang cenderung dangkal sehingga mengakibatkan konsentrasi SS di tepi danau lebih besar (Effendi, 2003).

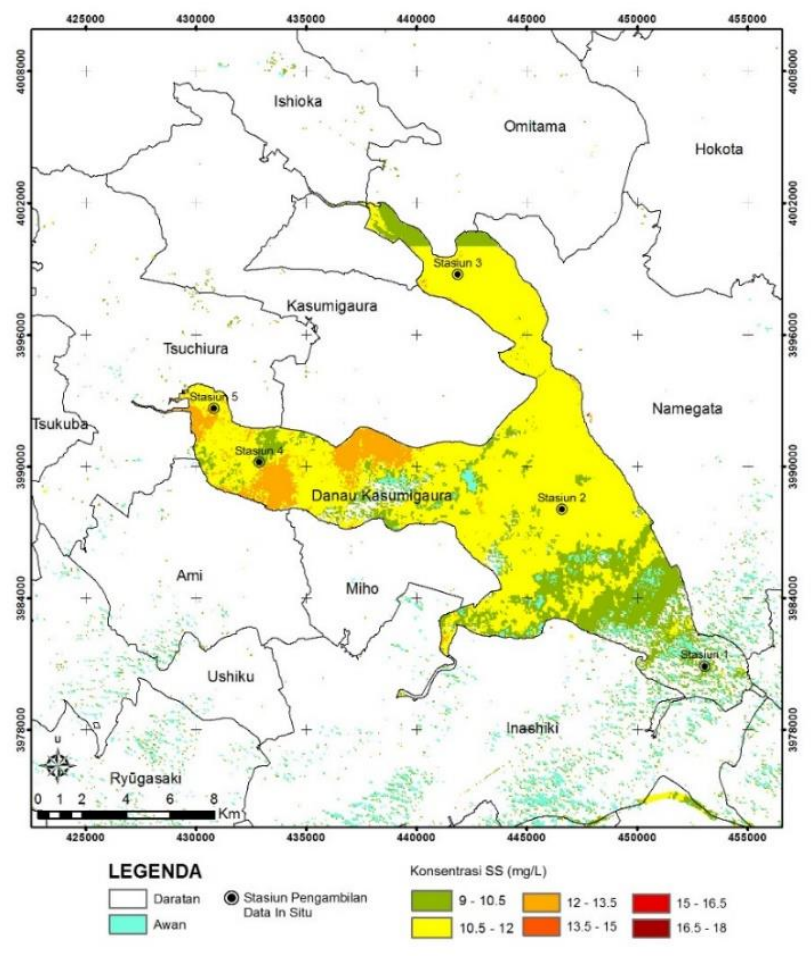

Gambar 7. Peta Estimasi Persebaran SS Danau Kasumigaura tanggal 29 November 2016

\section{KESIMPULAN}

Reflektan permukaan setelah melalui proses koreksi atmosfer Sen2Cor menghasilkan nilai yang lebih rendah dari reflektan sensor. Hasil dari reflektan permukaan ini kemudian diubah menjadi $\operatorname{Rrs}(\lambda)$ sehingga memiliki satuan yang sama dengan data in situ, yaitu $\mathrm{sr}^{-1}$. Nilai $\operatorname{Rrs}(\lambda)$ setelah dibandingkan dengan data in situ memiliki nilai yang lebih tinggi.

Hasil dari uji koefisien determinasi $\left(R^{2}\right)$ terhadap produk reflektan permukaan yang telah terkoreksi Sen2Cor, menghasilkan nilai 0,737. Hal ini menunjukkan bahwa $\operatorname{Rrs}(\lambda)$-Sen2Cor mampu menggambarkan nilai $\operatorname{Rrs}(\lambda)$ in situ dengan baik. Namun hasil uji akurasi RMSE dan NMAE masingmasing adalah sebesar 0,004 dan 114,087\%.
Tingginya nilai NMAE ini diakibatkan oleh jumlah data in situ yang terlalu sedikit dibandingkan luasan area penelitian. Sementara syarat nilai NMAE untuk bisa melakukan ektraksi parameter kualitas air adalah $\leq 30 \%$. Sehingga untuk data $\operatorname{Rrs}(\lambda)$ Sen2Cor ini, dianggap tidak akurat untuk digunakan perhitungan ekstraksi parameter kualitas air.

Akurasi dari hasil $\operatorname{Rrs}(\lambda)$ mempengaruhi nilai estimasi SS yang dihasilkan, hal ini dibuktikan dengan hasil validasi estimasi SS terhadap SS in situ. Pada uji koefisien determinasi $\left(\mathrm{R}^{2}\right), \mathrm{RSME}$ dan NMAE masing-masing adalah 0,$153 ; 5,665$; dan 24,965\%. Dari validasi estimasi SS ini, meskipun nilai NMAE menunjukkan angka $\leq 30 \%$, namun berdasarkan uji $\mathrm{R}^{2}$ dan RMSE estimasi SS menunjukkan hasil yang tidak akurat.

Dari peta persebaran estimasi SS yang diperoleh, nilai persebaran SS pada tanggal 27 Oktober 2016 lebih besar daripada nilai SS pada tanggal 29 November 2016, dimana nilai konsentrasi SS pada area tepi danau dan muara sungai lebih tinggi dibandingkan area tengah danau.

\section{UCAPAN TERIMA KASIH}

Penulis R.I.W. mengucapkan terima kasih kepada Bapak Lalu Muhamad Jaelani, S.T., M.Sc., Ph.D. selaku dosen pembimbing yang telah banyak membantu dalam penelitian ini sehingga penelitian ini dapat berjalan dengan lancar.

\section{DAFTAR PUSTAKA}

Effendi, H. (2003). Telaah Kualitas Air Bagi Pengelolaan Sumber Daya dan Lingkungan Perairan. Yogyakarta: Kanisius.

Han, L., \& Jordan, K. J. (2005). Estimating and Mapping Chlorophyll-a Concentration in Pensacola Bay, Florida using Landsat ETM+ data. International Journal of Remote Sensing, 5245-5254.

Jaelani, L. M., Limehuwey, R., Kurniadin, N., Pamungkas, A., Koenhardono, E. S., \& Sulisetyono, A. (2016). Estimation of TSS and Chl-a Concentration from Landsat 8-OLI: The Effect of Atmosphere and Retrieval Algorithm. IPTEK, 27(The Journal for Technology and Science), 16-23. 
Jaelani, L. M., Setiawan, F., \& Matsushita, B. (2015). Uji Akurasi Produk Reflektan-Permukaan Landsat Menggunakan Data In Situ di Danau Kasumigaura, Jepang. Prosiding Pertemuan IImiah Tahunan XX (pp. 464-470). Bogor: MAPIN.

Martin, S. (2004). An Introduction to Ocean Remote Sensing. UK: Cambridge University Press.

Ruddick, K., Ovidio, F., \& Rijkeboer, M. (2000). Atmospheric correction of SeaWiFs imagery for turbid coastal and inland water. Applied Optics, 897-912. 